\title{
PENGARUH LAMA BLANCHING DAN RUMUS PETIKAN DAUN TERHADAP KARAKTERISKTIK FISIK, KIMIA, SERTA SENSORIS TEH DAUN TIN (Ficus carica)
}

\author{
EFFECT OF BLANCHING AND THE AGE OF LEAVES ON PHYSICAL, CHEMICAL, AND \\ SENSORY CHARACTERISTICS OF FIG LEAF TEA (Ficus carica)
}

\author{
Bambang Sigit Amanto, Tiara Ni'mah Aprilia, Asri Nursiwi \\ Program Studi Ilmu Teknologi Pangan, Fakultas Pertanian, Universitas Sebelas Maret Surakarta \\ Email: asrinursiwi@gmail.com
}

Diserahkan [3 Desember 2019]; Diterima [30 Januari 2020]; Dipublikasi [16 Februari 2020]

\begin{abstract}
The fig (ficus carica) leaves contain various active compounds such as flavonoids, phenols, tannins, and quercetin. The fig leaf is used as raw material for making tea. In the manufacture of green tea the blanching process is carried out to inactivate the enzyme polyphenol oxidase. The purpose of this study was to determine the effect of blanching and the age of leaves on the physical characteristics (color), chemical characteristics (moisture content, total phenol, tannin content, and antioxidant activity), and sensory characteristics (color, taste, aroma, and overall). Fig leaf tea was processed following the processing of green tea, namely withering, rolling, drying and sorting. The study used two factors, namely blanching duration $(0.5,10,15$ minutes) and the age of leaves (young leaf : pick leaf 2 and 3 and mature leaf : pick leaf 4 and 5). The results showed that blanching duration and the age of leaf significantly affected physical (color steeping) and chemical characteristics (water content, phenol, tannin, and antioxidant activity) of fig leaf tea. The longer blanching the lower $L$ value and a value while the $b$ value will be higher. The longer blanching, the lower the chemical characteristics (water content, phenol, tannin, and antioxidant activity) of fig leaf tea. The older the leaves (pick leaf 4 and 5) increased the L value, but decreased the $a$ and $b$ value. The older the leaves the moisture content, tannin content, and antioxidant activity of fig leaf tea decreased. The sensory characteristics, blanching duration did not significantly affect the liking of colors and aromas but significantly affected the liking level of taste and overall of the fig leaf tea. The age of leaves did not significantly affect the liking level of color, aroma, and overall, but significantly affected the liking level of the taste of the fig leaf tea.
\end{abstract}

Keyword : fig leaf tea, ficus carica, blanching, the age of leaves, antioxidant activity

\section{ABSTRAK}

Daun tin yang berasal dari tanaman fig atau ficus carica mengandung berbagai senyawa aktif seperti flavonoid, fenol, tanin, dan quercetin. Daun tin ini salah satunya dimanfaatkan sebagai bahan baku pembuatan teh. Pada pembuatan teh hijau dilakukan proses pemanasan untuk menginaktivasi enzim polifenol oksidase. Tujuan dari penelitian ini adalah untuk mengetahui pengaruh lama blanching dan rumus petikan daun terhadap karakteristik fisik yaitu warna seduhan teh, karakteristik kimia yaitu kadar air, total fenol, kadar tanin, dan aktivitas antioksidan, serta karakteristik sensoris meliputi warna, rasa, aroma, dan overall. Teh daun tin diproses mengikuti cara pengolahan teh hijau, yaitu pelayuan, penggulungan, pengeringan, dan sortasi. Penelitian ini menggunakan dua faktor, yaitu lama blanching (0,5,10,15 menit) dan rumus petikan daun (petikan 2 dan 3 serta petikan 4 dan 5). Hasil penelitian menunjukkan bahwa lama blanching dan rumus petikan daun berpengaruh nyata terhadap karakteristik fisik (warna seduhan) dan kimia (kadar air, fenol, tanin, dan aktivitas antioksidan) teh daun tin. Semakin lama blanching akan menurunkan nilai L dan a seduhan teh sementara nilai b akan semakin tinggi. Semakin lama waktu blanching, karakteristik kimia (kadar air, fenol, tanin, dan aktivitas antioksidan) teh daun tin akan semakin menurun. Semakin tua daun (petikan 4 dan 5) akan menaikkan nilai L, akan tetapi menurunkan nilai a dan b. Semakin tua daun maka kadar air, kadar tanin, dan aktivitas antioksidan teh daun tin semakin menurun. Sedangkan untuk karakteristik sensoris, lama blanching tidak berpengaruh nyata terhadap kesukaan warna dan aroma namun berpengaruh nyata terhadap tingkat kesukaan rasa dan overall teh daun tin. Rumus petikan daun tidak berpengaruh nyata terhadap tingkat kesukaan warna, aroma, dan overall, namun berpengaruh nyata terhadap tingkat kesukaan rasa teh daun tin.

Kata Kunci : teh daun tin; ficus carica; blanching; rumus petikan; aktivitas antioksidan

\section{PENDAHULUAN}

Tanaman tin (Ficus carica) yang masuk ke dalam famili Moraceae, merupakan tanaman yang bisa tumbuh di negara tropis dan sub tropis. Buah, daun, dan akarnya secara tradisonal digunakan untuk mengatasi berbagai gangguan seperti pencernaan, 
pernafasan, radang dan kardiovaskuler (Patil et al., 2010). Senyawa kimia yang dapat diidentifikasi dari daun tin antara lain fenol, sesquiterpenes, flavonoid, tanin, dan asam organik (Oliviera et al., 2010). Selain itu daun tin juga mengandung senyawa kimia lain seperti coumarins, sterol, glikosida, alkaloid, dan saponin (Nebedum et al., 2010). Daun tin juga mengandung vitamin C dan vitamin E. Daun tin merupakan daun yang kaya akan senyawa fenolik. Kandungan total fenol yang terdapat pada daun tin sebesar 907,02 \pm 33,24 mg GAE/100g (Ghazi et al., 2012).

Pemanfaatan daun tin di Indonesia untuk saat ini baru terbatas pada produk teh, yaitu teh daun tin. Proses pembuatan teh yang tidak terlalu rumit dan mudah dilakukan dalam skala rumah tangga membuat produk teh daun tin ini semakin berkembang dan mulai banyak produsen yang mengolahnya. Karena manfaatnya yang cukup besar bagi tubuh manusia maka produk turunan dari tanaman tin ini semakin diminati masyarakat, termasuk teh daun tin.

Teh merupakan minuman yang mengandung kafein, yang diperoleh dengan menyeduh daun atau pucuk daun dari tanaman Camellia sinensis menggunakan air panas (Siringoringo et al., 2012). Minuman teh ini banyak dikonsumsi karena aroma dan rasanya yang khas. Pada awalnya, sebutan teh hanya ditujukan pada teh hasil tanaman Camellia sinensis, seperti teh hitam, teh hijau, dan teh oolong. Teh jenis lain yang telah dikenal yaitu teh herbal. Teh herbal merupakan hasil olahan teh yang tidak berasal dari daun teh tanaman Camellia sinensis. Bahan-bahan untuk pembuatan teh herbal pun kini semakin mudah didapat misalnya daun, biji, akar, atau buah kering (Inti, 2008).

Di Indonesia produk teh dari komoditi selain tanaman teh saat ini semakin berkembang, diantaranya teh dari daun kopi (Siringoringo dkk., 2012), teh dari daun gambir (Litbang Pertanian, 2014), teh dari daun jambu biji (Sanara, 2014), teh dari daun sirsak (Adri dan Hersoelistyorini, 2013), teh dari bunga rosella (Yuariski dan Suherman, 2012), teh dari daun kemangi, teh dari mahkota dewa, teh seledri (Hambali, 2006), teh dari kulit buah naga (Shofiati, 2014), dan teh dari bunga lotus (Kusumaningrum et al., 2013).

Produk teh daun tin saat ini sudah ada di pasaran, namun permasalahan yang muncul pada pengolahan teh berbahan daun tin adalah masih adanya bau khas yang kuat pada produk akhirnya. Bau khas yang muncul yaitu bau langu daun tin dan rasa pahit yang muncul pada olahan teh. Bau khas yang muncul ini juga banyak ditemui pada daun tin dimungkinkan karena adanya senyawa saponin yang terkandung pada daun tin. Saponin merupakan steroid atau triterpenoid glukosida yang dibatasi pada karbohidrat. Saponin menyebabkan rasa pahit, memiliki karakteristik berupa busa dan dapat larut dalam air dengan mudah. Selain itu adanya senyawa tanin diduga mempengaruhi rasa produk yang dihasilkan.

Menurut Nkafamiya et al. (2006), Adeboye dan Babajide (2010), senyawa antinutrisi seperti asam oksalat, tanin, $\mathrm{HCN}$, dan saponin yang terkandung dalam sayuran dapat menurun oleh proses blanching, terutama ketika proses blanching dilakukan menggunakan air panas. Pada penelitian ini proses pengolahan teh daun tin dilakukan seperti pada pengolahan teh hijau. Proses blanching pada teh hijau dilakukan untuk menginaktivasi enzim polifenol oksidase. Proses inaktivasi enzim polifenol oksidase yang dilakukan dalam pengolahan teh daun tin selain bertujuan untuk menghilangkan bau khas daun yang ada pada daun tin dan untuk menjaga warna teh agar tetap baik. Pada produk teh daun tin yang ada di pasaran, bau langu yang muncul menjadi salah satu hal yang kurang bisa diterima oleh konsumen.

Pemetikan daun tin dilakukan dengan menggunakan rumus petikan daun teh. Hal ini dilakukan untuk menjaga kualitas daun teh yang dihasilkan. Proses pemetikan yang dilakukan mengikuti rumus pemetikan daun teh pada umumnya yaitu petikan medium. Petikan medium merupakan pucuk daun yang dipetik dari daun ke-2 dari pucuk hingga daun ke-6. Rumus petikan daun akan mempengaruhi kandungan senyawa kimia pada daun teh yang dihasilkan (Rosida, 2015). Penelitian ini dilakukan untuk mengetahui pengaruh dari lama blanching 
dan rumus petikan daun terhadap karakteristik fisik, kimia, dan sensoris pada pembuatan teh daun tin.

\section{METODE PENELITIAN}

\section{Bahan}

Daun tin yang digunakan merupakan jenis Brown Turkey yang diperoleh dari Kebun Tin di Yogyakarta. Daun tin yang digunakan berasal dari proses pemetikan dari pucuk ke-2 sampai ke-5. Bahan analisis yang digunakan diantaranya aquades, metanol, $\mathrm{DPPH}$, asam galat folin ciocalteu, $\mathrm{Na} 2 \mathrm{CO} 3$, asam tanat (Merck)

\section{Alat}

Peralatan yang digunakan dalam penelitian ini diantaranya adalah panci, kompor, kabinet drier, timbangan analit, hot plate, spektrofotometer UV Vis, dan berbagai alat gelas.

\section{Tahapan Penelitian}

\section{Pemetikan Daun Tin}

Tahapan penelitian ini diawali dengan pemetikan daun tin sesuai dengan yang dibutuhkan yaitu daun ke-2 hingga ke-5 dihitung dari pucuk daun. Daun dipisahkan menjadi dua kelompok yaitu daun ke-2 hingga ke-3 dan daun ke-4 hingga ke-5. Pemetikan daun dilakukan hingga batang daun. Daun yang telah dipetik kemudian diproses menjadi teh.

\section{Pembuatan Teh Daun Tin}

Daun tin yang telah dipetik dan dikelompokkan berdasarkan rumus petikan, kemudian dilakukan penyortiran awal. Kemudian daun tin dicuci dengan air mengalir. Daun tin kemudian ditiriskan untuk mengurangi air yang menempel pada daun. Kemudian dilakukan proses blanching.
Blanching dilakukan dengan menggunakan uap dari air yang telah dididihkan. Lama waktu blanching yang digunakan yaitu 0 menit; 5 menit; 10 menit; dan 15 menit. Setelah proses blanching daun tin kemudian didinginkan selama \pm 10 menit. Dilakukan penggulungan selama \pm 10 menit kemudian dilakukan pengecilan ukuran $(0,5 \times 0,5 \mathrm{~cm})$. Kemudian daun tin dikeringkan dengan cabinet dryer dengan suhu $50^{\circ} \mathrm{C}$ selama 8 jam.

\section{Metode Analisis}

Analisis kadar air menggunakan metode termogravimetri (AOAC,1999), analisis total fenol menggunakan metode Folin ciaocalteau (Zulfahmi, 2012), analisis kadar tanin menggunakan metode Folin ciaocalteau (AOAC,1999), analisis aktivitas antioksidan menggunakan metode DPPH (Salazar-Aranda et al., 2009), analisis warna seduhan menggunakan cromameter (LAB) (Fatanah et al., 2016), analisis organoleptik menggunakan uji hedonik metode skoring ( Setyaningsih, 2010).

Data yang diperoleh kemudian diolah menggunakan metode Two Way Analysis of Variance (ANOVA). Jika terdapat perbedaan kemudian dilanjutkan dengan uji DMRT (Duncan Multiple Range Test) dengan taraf signifikansi $5 \%$.

\section{HASIL DAN PEMBAHASAN}

\section{Karakteristik Fisik Teh Daun Tin}

Warna merupakan sifat sensoris produk pangan yang pertama kali dilihat oleh konsumen. Pengukuran warna seduhan teh dilakukan dengan mengukur nilai Lightness (L), a, b, dan ${ }^{0}$ hue. Hasil analisis warna seduhan teh daun tin terlihat pada Tabel 1. 
Tabel 1 Analisis Warna Seduhan Teh Daun Tin dengan Perlakuan Lama Blanching dan Rumus Petikan Daun

\begin{tabular}{|c|c|c|c|c|c|}
\hline \multicolumn{6}{|c|}{$L^{*}$ (Lightness) } \\
\hline \multirow{2}{*}{$\begin{array}{l}\text { Rumus } \\
\text { Petikan }\end{array}$} & \multicolumn{4}{|c|}{ Lama Blanching } & \multirow{2}{*}{ Rata-rata } \\
\hline & 0 menit & 5 menit & 10 menit & 15 menit & \\
\hline Daun 2-3 & $53,773 \pm 0,369$ & $55,985 \pm 0,260$ & $56,552 \pm 0,285$ & $56,373 \pm 0,153$ & $55,671^{\mathrm{A}} \pm 1,168$ \\
\hline Daun 4-5 & $54,572 \pm 0,112$ & $57,510 \pm 0,211$ & $56,938 \pm 0,220$ & $54,537 \pm 0,093$ & $55,889^{\mathrm{B}} \pm 1,388$ \\
\hline Rata-rata & $54,172^{\mathrm{a}} \pm 0,492$ & $56,748^{\mathrm{c}} \pm 0,828$ & $56,745^{\mathrm{c}} \pm 0,315$ & $55,455^{\mathrm{b}} \pm 0,967$ & \\
\hline \multicolumn{6}{|c|}{$a^{*}$} \\
\hline Rumus & \multicolumn{4}{|c|}{ Lama Blanching } & \multirow{2}{*}{ Rata-rata } \\
\hline Petikan & 0 menit & 5 menit & 10 menit & 15 menit & \\
\hline Daun 2-3 & $-0,368 \pm 0,020$ & $-5,143 \pm 0,026$ & $-5,655 \pm 0,019$ & $-5,655 \pm 0,022$ & $-4,172^{\mathrm{A}} \pm 2,252$ \\
\hline Daun 4-5 & $-1,468 \pm 0012$ & $-3,847 \pm 0,014$ & $-3,852 \pm 0,013$ & $-2,022 \pm 0,012$ & $-2,797^{\mathrm{B}} \pm 1,093$ \\
\hline Rata-rata & $-0,918^{\mathrm{a}} \pm 0,575$ & $-4,495^{\mathrm{c}} \pm 0,678$ & $-4,753^{\mathrm{d}} \pm 0,942$ & $-3,772^{\mathrm{b}} \pm 1,829$ & \\
\hline \multicolumn{6}{|c|}{$b^{*}$} \\
\hline Rumus & \multicolumn{4}{|c|}{ Lama Blanching } & \multirow{2}{*}{ Rata-rata } \\
\hline Petikan & 0 menit & 5 menit & 10 menit & 15 menit & \\
\hline Daun 2-3 & $28,820 \pm 0,009$ & $41,395 \pm 0,014$ & $43,735 \pm 0,019$ & $44,750 \pm 0,009$ & $39,675^{\mathrm{B}} \pm 6,521$ \\
\hline Daun 4-5 & $22,023 \pm 0,021$ & $26,132 \pm 0,017$ & $27,473 \pm 0,014$ & $38,955 \pm 0,022$ & $30,708^{\mathrm{A}} \pm 7,088$ \\
\hline Rata-rata & $25,422^{\mathrm{a}} \pm 3,549$ & $33,763^{\mathrm{b}} \pm 7,971$ & $35,604^{\mathrm{c}} \pm 8,492$ & $40,887^{\mathrm{d}} \pm 2,811$ & \\
\hline \multicolumn{6}{|c|}{ Hue } \\
\hline Rumus & \multicolumn{4}{|c|}{ Lama Blanching } & \multirow{2}{*}{ Rata-rata } \\
\hline Petikan & 0 menit & 5 menit & 10 menit & 15 menit & \\
\hline Daun 2-3 & $89,268 \pm 0,040$ & $82,917 \pm 0,034$ & $82,632 \pm 0,026$ & $82,964 \pm 0,027$ & $84,445^{\mathrm{B}} \pm 2,847$ \\
\hline Daun 4-5 & $86,186 \pm 0,030$ & $81,626 \pm 0,028$ & $82,019 \pm 0,028$ & $87,029 \pm 0,019$ & $84,215^{\mathrm{A}} \pm 2,467$ \\
\hline Rata-rata & $87,727^{\mathrm{d}} \pm 1,610$ & $82,272^{\mathrm{a}} \pm 0,675$ & $82,326^{\mathrm{b}} \pm 0,321$ & $84,997^{\mathrm{c}} \pm 2,123$ & \\
\hline
\end{tabular}

\section{Merah-Hijau (nilai a)}

Nilai a adalah warna kromatik campuran merah dan hijau. Warna merah berada pada kisaran nilai 0 sampai +100 sedangkan warna hijau berada pada kisaran nilai 0 hingga -80. Semakin besar nilai positif a berarti warna semakin merah sedangkan jika nilai negatifnya semakin tinggi maka warnanya semakin hijau (Anjani et al., 2015). Berdasarkan penelitian, warna seduhan teh daun tin memiliki nilai a negatif. Hal ini berarti bahwa warna seduhan teh daun tin cenderung berwarna hijau. Berdasarkan analisis hasil statistik, lama blanching dan rumus petikan daun memberikan pengaruh yang nyata terhadap nilai a seduhan teh daun tin $(\mathrm{p}<0,05)$. Semakin lama proses blanching maka semakin turun warna hijau seduhan teh daun tin. Daun yang lebih muda (Petikan 2 dan 3) memiliki nilai a (warna hijau) yang lebih tinggi dibandingkan dengan daun tua. Hal ini sesuai dengan penelitian Felicia et al. (2016) tentang teh daun alpukat, bahwa teh daun alpukat yang berasal dari daun muda memiliki intensitas warna hijau yang lebih tinggi daripada daun tua.

\section{Biru-Kuning (nilai b)}

Notasi b adalah warna kromatik campuran biru kuning (Ardiyansyah dan Apriliyanti, 2016). Nilai $+b$ (positif) dari 0 sampai +70 untuk warna kuning dan nilai $-b$ (negatif) dari 0 sampai -70 untuk warna biru (Manera et al., 2012). Berdasarkan hasil penelitian nilai b yang diperoleh yaitu positif. Hal ini menandakan bahwa warna seduhan teh daun tin berwarna kekuningan. Berdasarkan hasil analisis statistik, lama blanching dan rumus petikan daun memberikan pengaruh yang nyata $(p<0,05)$ terhadap nilai $b$ seduhan teh daun tin. Semakin tinggi nilai b maka semakin pekat warna kuning yang dihasilkan. Proses blanching yang dilakukan membuat warna seduhan teh semakin kuning. Semakin tua daun, nilai b semakin berkurang. Hal ini menandakan bahwa pada seduhan teh daun tin yang berasal dari daun muda memiliki warna kuning yang lebih pekat dibandingkan seduhan teh yang berasal dari daun tua. Hal 
ini sesuai dengan hasil penelitian yang dikemukakan oleh Felicia et al.. (2016), yaitu nilai b pada daun muda lebih tinggi yaitu 34,81 sedangkan nilai b untuk daun tua sebesar 33,72. Penurunan warna ini dimungkinkan terjadi karena disfungi pigmen warna pada daun yang mulai menua.

\section{Nilai Hue $\left({ }^{0}\right.$ Hue $)$}

Nilai hue atau ${ }^{0}$ Hue merupakan panjang gelombang yang dominan yang menentukan arah warna dari suatu bahan atau produk (Winarno, 2008). Berdasarkan hasil penelitian nilai ${ }^{0}$ Hue seduhan teh daun tin adalah 82-87. Berdasarkan tabel deskripsi warna Hutching, 1999 maka seduhan teh daun tin berada pada warna yellow red (merah kekuningan). Teh daun tin diproses mengikuti pengolahan teh hijau, jadi warna seduhan yang dihasilkan berwarna kekuningan. Berdasarkan hasil analisis statistik, lama blanching dan rumus petikan daun memberikan pengaruh yang nyata terhadap ${ }^{0}$ Hue air seduhan teh $(\mathrm{p}<0,05)$. Nilai ${ }^{0}$ Hue lebih rendah pada teh yang dibuat dari daun tua dan semakin lama blanching maka nilai ${ }^{0}$ Hue akan semakin menurun. Teh daun tin berada pada rentang warna yellow-red atau merah kekuningan dimungkinkan terjadi karena sebagian klorofil telah ikut larut dengan air saat proses blanching dilakukan. Berkurangnya pigmen klorofil ini menyebabkan warna seduhan akan kehilangan warna hijau, dan digantikan oleh warna kuning dari karoten. Selain itu degradasi klorofil yang terjadi akibat proses pemanasan yang menghasilkan feofitin juga mempengaruhi munculnya warna merah kecoklatan pada seduhan teh.

\section{Karakteristik Kimia Teh Daun Tin}

\section{Kadar Air}

Berdasarkan hasil analisis statistik, lama blanching dan rumus petikan daun berpengaruh nyata terhadap kadar air teh daun tin $(p<0,05)$ (Tabel 2). Berdasarkan hasil penelitian, kadar air teh daun tin dengan perlakuan blanching 0 menit atau tanpa blanching memiliki rata-rata kadar air yang tinggi yaitu $8,84 \%$. Nilai kadar air tersebut lebih tinggi apabila dibandingkan dengan teh yang diberi perlakuan blanching. Kadar air teh kering dengan perlakuan blanching memiliki nilai kadar air yang lebih rendah, yang sudah sesuai dengan standar teh kering menurut SNI (2003) yaitu maksimal sebesar $8 \%$. Kadar air teh kering berdasarkan penelitian memiliki nilai dibawah $8 \%$.

Kadar air teh daun tin dengan perlakuan rumus petikan daun menunjukkan bahwa kadar air teh yang berasal dari petikan daun ke-2 hingga ke-3 memiliki nilai kadar air yang lebih tinggi dibandingkan dengan daun yang berasal dari petikan ke-4 hingga ke-5. Teh yang berasal dari petikan atas memiliki kadar air sebesar 7,238\% sedangkan teh yang berasal dari petikan bawah memiliki kadar air sebesar $6,953 \%$. Nilai kadar air tersebut telah sesuai dengan standar teh kering menurut SNI yaitu $8 \%$. Salah satu faktor yang mempengaruhi kadar air adalah kadar air bahan mentah. Berdasarkan penelitian dari Supriyanto et al. (2014) tentang teh daun kakao, teh daun kakao dari petikan atas memiliki nilai kadar air lebih tinggi daripada teh dari petikan daun bawah.

Tabel 2 Nilai Kadar Air Teh Daun Tin dengan Variasi Perlakuan Lama Blanching dan Rumus Petikan Daun

\begin{tabular}{|c|c|c|c|c|c|}
\hline \multicolumn{6}{|c|}{ KADAR AIR (\%) } \\
\hline \multirow{2}{*}{$\begin{array}{c}\text { Rumus } \\
\text { Petikan } \\
\text { Daun }\end{array}$} & \multicolumn{4}{|c|}{ Lama Blanching } & \multirow{2}{*}{ Rata-rata } \\
\hline & 0 menit & 5 menit & 10 menit & 15 menit & \\
\hline $\begin{array}{c}\text { Daun ke- } \\
2-3\end{array}$ & $8,775 \pm 0,174$ & $6,267 \pm 0,127$ & $6,518 \pm 0,064$ & $7,390 \pm 0,114$ & $7,238^{\mathrm{A}} \pm 1,009$ \\
\hline $\begin{array}{c}\text { Daun ke- } \\
4-5\end{array}$ & $8,912 \pm 0,170$ & $6,565 \pm 0,074$ & $6,160 \pm 0,055$ & $6,175 \pm 0,069$ & $6,953^{\mathrm{B}} \pm 1,171$ \\
\hline Rata-rata & $8,844^{\mathrm{c}} \pm 0,179$ & $6,416^{\mathrm{a}} \pm 0,185$ & $6,339^{\mathrm{a}} \pm 0,195$ & $6,783^{\mathrm{b}} \pm 0,641$ & \\
\hline
\end{tabular}

Keterangan: Tanda superscript dengan huruf yang berbeda pada baris atau kolom yang sama menunjukkan adanya beda nyata $(\alpha=5 \%)$ 
Teh yang terbuat dari daun petikan atas memiliki kadar air sebesar $4,21 \%$ dan daun yang berasal dari petikan bawah sebesar $3,70 \%$. Teh yang berasal dari petikan daun ke-4-5 atau daun yang tua memiliki jumlah sel-sel yang sudah tidak aktif didalamnya. Sel-sel yang sudah rusak ini menganggu jalannya transportasi air dari akar ke daun, sehingga dalam daun yang tua mengandung lebih sedikit air. Tingginya kadar air pada tanaman muda karena pada bagian tanaman yang muda memiliki lebih banyak sel yang aktif bila dibandingkan dengan daun tua (Lakitan, 1993).

\section{Total Fenol}

Berdasarkan hasil analisis statistik diperoleh $\mathrm{p}<0,05$ (Tabel 3), sehingga perlakuan yang diberikan, yaitu lama waktu banching dan rumus petikan daun berpengaruh nyata terhadap kadar total fenol teh daun tin. Berdasarkan hasil penelitian, semakin lama waktu blanching maka total fenol teh daun tin akan berkurang. Total fenol teh daun tin dengan perlakuan blanching 0 menit sebesar $0,432 \%$ dan total fenol teh daun tin dengan perlakuan blanching 15 menit sebesar 0,354\%.
Penurunan total fenol dalam teh daun tin disebabkan karena adanya proses pemanasan. Fenol merupakan senyawa yang mudah rusak karena perlakuan panas. Panas yang digunakan saat pembuatan teh daun tin dimungkinkan yang menjadi penyebab turunnya nilai total fenol.

Berdasarkan hasil penelitian, total fenol seduhan teh dari daun muda lebih rendah bila dibandingkan dengan seduhan teh dari daun yang tua. Kadar fenol teh dari daun muda memiliki nilai rata-rata sebesar $0,372 \%$, sedangkan teh dari daun tua memiliki nilai rata-rata sebesar $0,405 \%$. Berdasarkan penelitian yang dilakukan oleh Felicia dkk. (2016) tentang teh herbal daun alpukat, mendapatkan hasil yaitu total fenol teh dari daun alpukat muda lebih rendah daripada teh dari daun alpukat tua. Total fenol teh daun alpukat muda sebesar 11,42 mg GAE/gram sedangkan total fenol teh daun alpukat tua sebesar 18,96 mg GAE/gram. Menurut Aziz dan Jack (2015), selama pertumbuhan, tanaman akan mensintesis metabolit sekunder dan senyawa bioaktif dengan jumlah yang berbeda dipengaruhi oleh morfologi daun dan bertambahnya usia daun.

Tabel 3 Nilai Total Fenol Teh Daun Tin dengan Variasi Perlakuan Lama Blanching dan Rumus Petikan Daun

\begin{tabular}{cccccc}
\hline \multicolumn{5}{c}{ TOTAL FENOL (\%) } & Rata-rata \\
\hline \multirow{2}{*}{$\begin{array}{c}\text { Rumus } \\
\text { Petikan } \\
\text { Daun }\end{array}$} & 0 menit & 5 menit & 10 menit & 15 menit & \\
\cline { 2 - 5 } & \multicolumn{4}{c}{ Lama Blanching } & \\
\hline $\begin{array}{c}\text { Daun } \\
\text { ke-2-3 } \\
\begin{array}{c}\text { Daun } \\
\text { ke-4-5 }\end{array}\end{array}$ & $0,430 \pm 0,001$ & $0,359 \pm 0,001$ & $0,354 \pm 0,001$ & $0,346 \pm 0,001$ & $0,372^{\mathrm{A}} \pm 0,034$ \\
\hline $\begin{array}{c}\text { Rata- } \\
\text { rata }\end{array}$ & $0,432^{\mathrm{d}} \pm 0,002$ & $0,389^{\mathrm{c}} \pm 0,031$ & $0,380^{\mathrm{b}} \pm 0,027$ & $0,354^{\mathrm{a}} \pm 0,008$ & \\
\hline
\end{tabular}

Keterangan: Tanda superscript dengan huruf yang berbeda pada baris atau kolom yang sama menunjukkan adanya beda nyata $(\alpha=5 \%)$

\section{Kadar Tanin}

Tanin merupakan senyawa turunan dari polifenol yang mempengaruhi rasa dan warna dari bahan makanan. Hasil analisis kadar tanin terlihat pada Tabel 4.

Hasil analisis statistik menunjukkan bahwa lama blanching dan rumus petikan daun memiliki pengaruh nyata terhadap kadar tanin teh daun tin $(\mathrm{p}<0,05)$. Adanya proses pemanasan (blanching) dalam pembuatan teh daun tin mengakibatkan terjadinya oksidasi komponen polifenol dengan penambahan oksigen. Semakin tinggi suhu maka senyawa tanin akan rusak. Rusaknya senyawa tanin ini akan menyebabkan rendahnya kadar tanin yang diperoleh. 
Tabel 4 Kadar Tanin Teh Daun Tin dengan Variasi Perlakuan Lama Blanching dan Rumus Petikan Daun

\begin{tabular}{|c|c|c|c|c|c|}
\hline \multicolumn{6}{|c|}{ KADAR TANIN(\%) } \\
\hline \multirow{2}{*}{$\begin{array}{c}\text { Rumus } \\
\text { Petikan } \\
\text { Daun }\end{array}$} & \multicolumn{4}{|c|}{ Lama Blanching } & \multirow[b]{2}{*}{ Rata-rata } \\
\hline & 0 menit & 5 menit & 10 menit & 15 menit & \\
\hline $\begin{array}{c}\text { Daun } \\
\text { ke-2-3 }\end{array}$ & $0,0233 \pm 0,0001$ & $0,0216 \pm 0,0001$ & $0,0186 \pm 0,0001$ & $0,0174 \pm 0,0001$ & $0,0202^{\mathrm{B}} \pm 0,0024$ \\
\hline $\begin{array}{l}\text { Daun } \\
\text { ke-4-5 }\end{array}$ & $0,0223 \pm 0,0001$ & $0,0217 \pm 0,0000$ & $0,0184 \pm 0,0001$ & $0,0180 \pm 0,0001$ & $0,0201^{\mathrm{A}} \pm 0,0019$ \\
\hline $\begin{array}{c}\text { Rata- } \\
\text { rata }\end{array}$ & $0,0228^{\mathrm{d}} \pm 0,0005$ & $0,0216^{\mathrm{c}} \pm 0,0001$ & $0,0185^{\mathrm{b}} \pm 0,001$ & $0,0177^{\mathrm{a}} \pm 0,0003$ & \\
\hline
\end{tabular}

Keterangan: Tanda superscript dengan huruf yang berbeda pada baris atau kolom yang sama menunjukkan adanya beda nyata $(\alpha=5 \%)$

Berdasarkan hasil penelitian, kadar tanin yang diperoleh semakin menurun seiring dengan semakin lama waktu blanching yang dilakukan. Blanching pada daun tin mengakibatkan senyawa tanin terdegradasi menjadi senyawa yang lebih sederhana. Selain pemanasan, kadar tanin yang turun juga disebabkan oleh umur daun. Daun yang lebih tua akan memiliki nilai tanin yang lebih rendah dari daun muda. Karena semakin tua daun maka tanin yang terkandung dalam daun akan semakin berkurang (Mahmoudi, 2016).

\section{Aktivitas Antioksidan}

Antioksidan merupakan senyawa yang dapat menghambat reaksi oksidasi, dengan mengikat radikal bebas. Konsumsi antioksidan dalam jumlah memadai dapat menurunkan resiko penyakit degeneratif, seperti kardiovaskular, kanker, aterosklerosis, osteoporosis, dan lain-lain (Winarsi, 2007). Hasil analisis aktivitas antioksidan pada teh daun tin terlihat seperti pada Tabel 5.

Berdasarkan hasil analisis statistik, lama blanching dan rumus petikan berpengaruh nyata terhadap aktivitas antioksidan teh daun tin $(\mathrm{p}<0,05)$. Dari Tabel 5 terlihat bahwa semakin lama waktu blanching aktivitas antioksidan semakin menurun. Aktivitas antioksidan teh daun tin menurun dari $92,982 \%$ menjadi $83,765 \%$ saat diberi perlakuan blanching selama 15 menit. Perlakuan pemanasan dapat mempercepat oksidasi terhadap antioksidan yang terkandung dalam bahan dan mengakibatkan penurunan aktivitas antioksidan dengan tingkatan yang berbeda sesuai dengan jenis komponen yang berperan dalam antioksidasi (Muawanah et al., 2012). Aktivitas antioksidan dalam teh daun tin dipengaruhi oleh total fenol (Tabel 3) dan kadar tanin (Tabel 4). Dari Tabel 3 dan Tabel 4 juga menunjukkan hal yang sama bahwa kadar total fenol dan kadar tanin semakin menurun dengan meningkatnya waktu blanching.

Tabel 5 Aktivitas Antioksidan Teh Daun Tin dengan Variasi Perlakuan Lama Blanching dan Rumus Petikan Daun

\begin{tabular}{|c|c|c|c|c|c|}
\hline \multicolumn{6}{|c|}{ AKTIVITAS ANTIOKSIDAN (\%) } \\
\hline \multirow{2}{*}{$\begin{array}{c}\text { Rumus } \\
\text { Petikan } \\
\text { Daun }\end{array}$} & \multicolumn{4}{|c|}{ Lama Blanching } & \multirow[b]{2}{*}{ Rata-rata } \\
\hline & 0 menit & 5 menit & 10 menit & 15 menit & \\
\hline $\begin{array}{c}\text { Daun } \\
\text { ke-2-3 }\end{array}$ & $92,690 \pm 0,262$ & $91,520 \pm 0,262$ & $89,376 \pm 0,302$ & $86,842 \pm 0,262$ & $90,102^{\mathrm{B}} \pm 2,290$ \\
\hline $\begin{array}{c}\text { Daun } \\
\text { ke-4-5 }\end{array}$ & $93,275 \pm 0,262$ & $85,478 \pm 0,302$ & $84,113 \pm 0,302$ & $80,607 \pm 0,302$ & $85,843^{\mathrm{A}} \pm 4,767$ \\
\hline $\begin{array}{c}\text { Rata- } \\
\text { rata }\end{array}$ & $92,982^{\mathrm{d}} \pm 0,394$ & $88,499^{\mathrm{c}} \pm 3,167$ & $86,745^{\mathrm{b}} \pm 2,763$ & $83,765^{a} \pm 3,319$ & \\
\hline
\end{tabular}

Keterangan: Tanda superscript dengan huruf yang berbeda pada baris atau kolom yang sama menunjukkan adanya beda nyata $(\alpha=5 \%)$ 
Pada Tabel 5 juga terlihat bahwa aktivitas antioksidan pada daun muda lebih tinggi dibandingkan dengan daun tua. Hal ini sesuai dengan yang dikemukakan oleh Mahmoudi et al. (2016) bahwa daun yang lebih tua memiliki aktivitas antioksidan yang lebih rendah daripada daun muda. Dari hasil analisis kadar tanin (Tabel 4) juga menunjukkan hal yang serupa, yaitu pada daun yang lebih muda memiliki kadar tanin yang lebih tinggi. Akan tetapi untuk kadar total fenol, pada daun tua memiliki kadar yag lebih tinggi. Hal ini diduga adanya senyawa lain yang bukan termasuk senyawa fenol yang terdeteksi sebagai senyawa antioksidan.

\section{Karakteristik Sensoris Teh Daun Tin}

Analisis sensoris yang digunakan dalam penelitian ini adalah uji hedonik (kesukaan) metode skoring pada 8 sampel seduhan teh daun tin yang berbeda.

Tabel 6 Karakteristik Organoleptik Teh Daun Tin dengan Perlakuan Lama Blanching dan Rumus Petikan Daun

\begin{tabular}{|c|c|c|c|c|c|}
\hline \multicolumn{6}{|c|}{ Warna } \\
\hline \multirow{2}{*}{$\begin{array}{l}\text { Rumus } \\
\text { Petikan }\end{array}$} & \multicolumn{4}{|c|}{ Lama Blanching } & \multirow{2}{*}{ Rata-rata } \\
\hline & 0 menit & 5 menit & 10 menit & 15 menit & \\
\hline Daun 2-3 & $3,633 \pm 1,033$ & $3,633 \pm 0,928$ & $3,767 \pm 1,040$ & $3,700 \pm 0,702$ & $3,683^{\mathrm{A}} \pm 0,926$ \\
\hline Daun 4-5 & $3,333 \pm 0,959$ & $3,533 \pm 0,937$ & $3,700 \pm 0,750$ & $3,767 \pm 0,774$ & $3,583^{\mathrm{A}} \pm 0,866$ \\
\hline Rata-rata & $3,483^{\mathrm{a}} \pm 0,999$ & $3,583^{\mathrm{a}} \pm 0,926$ & $3,733^{\mathrm{a}} \pm 0,899$ & $3,733^{\mathrm{a}} \pm 0,733$ & \\
\hline \multicolumn{6}{|c|}{ Rasa } \\
\hline Rumus & \multicolumn{4}{|c|}{ Lama Blanching } & \multirow{2}{*}{ Rata-rata } \\
\hline Petikan & 0 menit & 5 menit & 10 menit & 15 menit & \\
\hline Daun 2-3 & $2,100 \pm 1,062$ & $2,667 \pm 0,959$ & $3,033 \pm 1,159$ & $2,100 \pm 0,845$ & $2,475^{\mathrm{A}} \pm 1,077$ \\
\hline Daun 4-5 & $2,567 \pm 1,006$ & $2,733 \pm 0,980$ & $3,200 \pm 1,031$ & $2,600 \pm 1,037$ & $2,775^{\mathrm{B}} \pm 1,033$ \\
\hline Rata-rata & $2,333^{\mathrm{a}} \pm 1,052$ & $2,700^{\mathrm{a}} \pm 0,962$ & $3,117^{\mathrm{b}} \pm 1,091$ & $2,350^{\mathrm{a}} \pm 0,971$ & \\
\hline \multicolumn{6}{|c|}{ Aroma } \\
\hline Rumus & \multicolumn{4}{|c|}{ Lama Blanching } & \multirow{2}{*}{ Rata-rata } \\
\hline Petikan & 0 menit & 5 menit & 10 menit & 15 menit & \\
\hline Daun 2-3 & $2,967 \pm 1,066$ & $3,367 \pm 0,964$ & $3,400 \pm 0,894$ & $3,200 \pm 0,761$ & $3,233^{\mathrm{A}} \pm 0,932$ \\
\hline Daun 4-5 & $3,133 \pm 1,042$ & $3,233 \pm 0,679$ & $3,233 \pm 0,817$ & $3,400 \pm 0,814$ & $3,250^{\mathrm{A}} \pm 0,843$ \\
\hline Rata-rata & $3,050^{\mathrm{a}} \pm 1,048$ & $3,300^{\mathrm{a}} \pm 0,829$ & $3,317^{\mathrm{a}} \pm 0,853$ & $3,300^{\mathrm{a}} \pm, 788$ & \\
\hline \multicolumn{6}{|c|}{ Overall } \\
\hline Rumus & \multicolumn{4}{|c|}{ Lama Blanching } & \multirow{2}{*}{ Rata-rata } \\
\hline Petikan & 0 menit & 5 menit & 10 menit & 15 menit & \\
\hline Daun 2-3 & $2,333 \pm 0,802$ & $2,900 \pm 0,845$ & $3,167 \pm 1,020$ & $2,533 \pm 0,776$ & $2,733^{\mathrm{A}} \pm 0,914$ \\
\hline Daun 4-5 & $2,733 \pm 0,868$ & $2,900 \pm 0,885$ & $3,100 \pm 0,845$ & $2,833 \pm 0,834$ & $2,892^{\mathrm{A}} \pm 0,858$ \\
\hline Rata-rata & $2,533^{\mathrm{a}} \pm 0,853$ & $2,900^{\mathrm{bc}} \pm 0,858$ & $3,133^{\mathrm{c}} \pm 0,929$ & $2,683^{\mathrm{ab}} \pm 0,813$ & \\
\hline
\end{tabular}

Keterangan: Tanda superscript dengan huruf yang berbeda pada baris dan kolom yang sama menunjukkan adanya beda nyata $(\alpha=5 \%)$

Skala hedonik $1=$ sangat tidak suka, $2=$ tidak suka, $3=$ Biasa $/$ Netral, $4=$ suka, $5=$ sangat suka
Parameter yang dinilai meliputi kesukaan terhadap warna, aroma, rasa dan overall. Hasil analisis sensoris dapat dilihat pada Tabel 6.

\section{Warna}

Proses blanching pada pengolahan teh memiliki keuntungan yaitu warna air seduhan agak lebih kehijauan dan lebih terang (Yulianto, et al., 2006). Daun teh yang diberi perlakuan pemanasan memiliki warna seduhan yang lebih terang bila dibandingkan dengan yang tidak diberi perlakuan pemanasan. Akan tetapi berdasarkan hasil analisis statistik untuk parameter warna, rumus petikan daun dan lama blanching tidak memberikan pengaruh yang berbeda nyata terhadap kesukaan terhadap warna seduhan teh daun tin $(\mathrm{p}>0,05)$. 


\section{Rasa}

Adanya senyawa flavonoid dan tanin pada daun tin akan mempengaruhi rasa yang muncul pada produk teh daun tin. Berdasarkan hasil analisis statistik, lama blanching dan rumus petikan daun memberikan pengaruh yang nyata terhadap kesukaan terhadap rasa teh daun tin $(p>0,05)$. Blanching mengghasilkan rasa teh daun tin yang lebih disukai. Proses blanching yang dilakukan terhadap daun tin akan mengurangi rasa sepat yang muncul (Yulianto et al., 2010). Pada daun yang lebih tua menghasilkan teh daun tin dengan rasa yang lebih disukai. Hasil ini sejalan dengan hasil kadar tanin (Tabel 5), dimana pada daun yang lebih tua kadar tanin lebih rendah sehingga rasa sepat yang muncul juga lebih kecil.

\section{Aroma}

Aroma pada bahan pangan bisa timbul secara alami maupun karena proses pengolahan, seperti penyangraian, pemanggangan, dan proses lainnya. Aroma juga bisa berkurang akibat suatu proses pengolahan misalnya blanching (Barcarolo et al., 1996). Akan tetapi berdasarkan hasil analisis statistik untuk parameter aroma, lama blanching dan rumus petikan daun tidak memberikan pengaruh yang berbeda nyata terhadap kesukaan terhadap aroma seduhan teh daun tin $(p>0,05)$.

\section{Overall}

Berdasarkan hasil analisis statistik, lama blanching memberikan pengaruh yang nyata terhadap kesukaan teh daun tin secara keseluruhan/ overall. Akan tetapi rumus petikan daun tidak memberikan pengaruh yang nyata terhadap kesukaan teh daun tin secara keseluruhan/ overall ( $p>0,05)$. Hal ini sejalan dengan kadar tanin, senyawa penyebab rasa sepet pada teh daun tin, waktu blanching yang lebih lama menurunkan secara nyata kadar tanin pada seduhan teh daun tin.

\section{KESIMPULAN}

Lama blanching dan rumus petikan daun berpengaruh nyata terhadap karakteristik fisik (warna seduhan) dan kimia (kadar air, fenol, tanin, dan aktivitas antioksidan) teh daun tin. Semakin lama blanching akan menurunkan nilai $\mathrm{L}$ dan a seduhan teh sementara nilai b akan semakin tinggi. Semakin lama waktu blanching, karakteristik kimia (kadar air, fenol, tanin, dan aktivitas antioksidan) teh daun tin akan semakin menurun. Semakin tua daun (petikan 4 dan 5) akan menaikkan nilai L, akan tetapi menurunkan nilai a dan b. Semakin tua daun maka kadar air, kadar tanin, dan aktivitas antioksidan teh daun tin semakin menurun. Sedangkan untuk karakteristik sensoris, lama blanching tidak berpengaruh nyata terhadap kesukaan warna dan aroma namun berpengaruh nyata terhadap tingkat kesukaan rasa dan overall teh daun tin. Rumus petikan daun tidak berpengaruh nyata terhadap tingkat kesukaan warna, aroma, dan overall, namun berpengaruh nyata terhadap tingkat kesukaan rasa teh daun tin.

\section{DAFTAR PUSTAKA}

Adeboye, A. S., \& Babajide, J. M. 2010. Effect of Processing Methods on Antinutrients in Selected Leafy Vegetables. Nigerian Food Journal, 25, 77-87.

Adri, Delvi dan Wikanastri Hersoelistyorini. 2013. Aktivitas Antioksidan dan Sifat Organoleptik Teh Daun Sirsak (Annona muricata Linn.) Berdasarkan Variasi Lama Pengeringan. Jurnal Pangan \& Gizi, Vol. 04 No. 07 : 1-12.

Anjani, Puncak, P., Andrianti, S., Widyaningsih, T.D. 2015. Pengaruh Penambahan Pandan Wangi dan Kayu Manis Pada Teh Herbal Kulit Salak Bagi Penderita Diabetes. Jurnal Pangan dan Agroindustri, 3 (1).

AOAC. 1999. Official Methods of Analysis of The Association Analytical Chemistry. AOAC International. Gaithersburg, Washington D. C.

Ardiyansyah dan Apriliyanti, M. 2016. Karakteristik Kimia Teh Kulit Melinjo. Jurnal Ilmiah Inovasi, 1 (2). 
Aziz, A., dan R. Jack. 2015. Total Phenolic Content and Antioxidant Activity in Nypa fruticans Extracts. Journal of Sustainability Science and Management 10 (1) : 87-91.

Balai Besar Penelitian dan Pengembangan Pascapanen Pertanian. 2014. Teh Daun Gambir. Warta Penelitian dan Pengembangan Pertanian, Vol. 36 No. 5 :10-11.

Barcarolo, R., C. Tutta., dan P. Cason dalam Nollet, L.M.L. 1996. Handbook of Food Analysis. Marcell Dekker, Inc. New York.

Fatanah, Dian Nashiela., Noriham Abdullah, Nooraain Hashim, and Azizah Abd Hamid. 2016. Antioxidant Activity, Colour and Mineral Content of Herbal Tea Prepared from Cosmos caudatus leaves at different Maturity Stages. Malaysian Journal of Analytical Sciences, Vol. 20 N0. 3 : 607-617.

Felicia, Naomi, I. Wayan Rai Widarta, And Ni Luh Ariyusasrini. 2016. Pengaruh Ketuaan Daun Dan Metode Pengolahan Terhadap Aktivitas Antioksidan Dan Karakteristik Sensoris Teh Herbal Bubuk Daun Alpukat (Persea Americana Mill.). Jurnal Ilmu Dan Teknologi Pangan (Itepa) 5.2: 85-94.

Ghazi F, Rahmat A, Yassin Z, Ramli NS, Buslima NA. 2012. Determination of total polyphenol and nutritional composition of two different types of Ficus carica leaves cultivated in Saudi Arabia. Pak J Nutr. 11(11) : 1061-1065.

Hambali, Erliza., Muhammad Zein Nasution dan Ersi Herliana. 2006. Membuat Aneka Herbal Teh. Penebar Swadaya. Jakarta.

Hutching, J.B. 1999. Food Color and Appearance $2^{\text {nd }}$ ed. A Chapman and Hall Food Science Book, an Aspen Publ. Gaithersburg, Maryland.

Inti, K. 2008. Teh Herbal Minuman Berkhasiat Pemulih Kesehatan. Gramedia Pustaka Utama. Jakarta.
Kusumaningrum, Ria. Agus Supriadi dan Siti Hanggita RJ. 2013. Karakteristik dan Mutu Teh Bunga Lotus (Nelumbo nucifera). FISTECH Vol II No. 01 : 921.

Lakitan, B. 1993. Dasar-Dasar Fisiologi Tumbuhan. PT Rajagrafindo Persada. Jakarta.

Mahmoudi, S., Khali M. Benkhaled, A., Benamirouche, K and Baiti I. 2016. Phenolic and flavonoid content,antioxidant and antimicrobial activities of leaf extract from ten Algerian Ficus carica L. Varieties. Asian Pac. J. Trop. Biomed 6 (3) : 239-245.

Manera, F.J., Martinez, J.M.B., Conesa, A., Porras, I. 2012. Relationship Between Air Temperature and Degreening of Lemon (Citrus lemon L. Burm. f.) Peel Color During Maturation. Australian Journal of Crop Science, 6 (6).

Muawanah, Anna., Ira Djajanegara. A. Sa'duddin, Dede Sukandar, dan Nani Radiastuti. 2012. Penggunaan Bunga Kecombrang dalam Proses Formulasi Permen Jelly. Valensi 2 (4) : 526-527.

Nebedum, JO, Udeafor, PC, Okeke, CU. 2010. Comparative effects of ethanolic extract of Ficus carica and Mucuna pruriens leaves on haematological parameters in albino rats. Biokemistri, $22(2)$ : 77-84.

Nkafamiya, I. I., Manji, A. J., Modibbo, U. U., \& Umaru, H. A. (2006). Biochemical Evaluation of Casspourea congoensis (Tunti) and Nuclea latifloia (Luzzi). Fruits. African Journal Biotechnol, 6 (19), 2461-2463.

Olievera, AP., LR Silva, PGD Pinho et al. 2010. Volatile Profilinf of Ficus carica Varieties by HS-SPME and GC-IT-MS. Food Chemistry Vol. 123 No. 2 : 548557.

Patil VV, Bhangale SC, Patil VR. 2010. Evaluation of anti-pyretic potential of Ficus carica leaves. Int J Pharmaceut Sci Rev \& Res. 2 (2) : 48-50. 
Rosida, Dedin F. Dan Dina Amalia. 2015. Kajian Pengendalian Mutu Teh Hitam Crushing, Tearing, Curling. J. Rekapangan Vol. 9 No. 2 : 59-66.

Salazar-Aranda R, Perez-Lopez LA, LopezArroyo J, Alanis_Garza BA, and Torres NW. 2009. Antimicrobial and antioxidant activities of plants from northeast of Mexico. eCAm 1-6.

Sanara, Fajri. 2014. Pembuatan Teh Daun Jambu Biji (Psidium guajava L.) Menggunakan Beberapa Metode Pengolahan. Skripsi Universitas Andalas.

Setyaningsih, Dwi, Anton Apriyantono, Maya Puspita Sari. 2010. Analisa Sensori Untuk Industri Pangan dan Agro. Bogor: IPB Press.

Shofiati, Atik., M.A.M. Andriani, dan Choirul Anam. 2014. Kajian Kapasitas Antioksidan dan Penerimaan Sensoris Teh Celup Kulit Buah Naga (Pitaya Fruit) dengan Penambahan Kulit Jeruk Lemon dan Stevia. Jurnal Teknosains Pangan Vol. 3 No. 2 : 5-13.

Siringoringo, Freddy Hotmaruli Tua, Zulkifli Lubis, dan Rona J. Nainggolan. 2012. Studi Pembuatan Teh Daun Kopi. J. Rekasaya Pangan dan Pertanian, Vol. 1 No.1:1-5.

Supriyanto. Purnama Darmadji, dan Iik Susanti. 2014. Studi Pembuatan Teh Daun Tanaman Kakao (Theobroma cacao L.) sebagai Minuman Penyegar. Agritech Vol. 34 No. 4 : 422-429.

Winarno, F.G. 2008. Kimia Pangan dan Gizi. PT Gramedian Pustaka Utama. Jakarta.

Winarsi, H. 2007. Antioksidan Alami dan Radikal Bebas. Potensi dan Aplikasinnya dalam Kesehatan. Kanisius. Yogyakarta.

Yuariski, Oki dan Suherman. 2012. Pengeringan Bunga Rosella (Hibiscus sabdariffa) Menggunakan Pengering Rak Udara Resirkulasi. Jurnal Teknologi Kimia dan Industri, Vol. 1 No. 1.
Yulianto, M.E., Senin, dan Ariwibowo, D. 2006. Model Perpindahan Panas Teknologi Steaming Proses Inaktivasi Enzim Polifenol Oksidase dalam Pengolahan Teh Hijau Berkatekin Tinggi. Laporan Sementara Penelitian Fundamental DIKTI.

Zulfahmi dan Dwi Eva Nirmagustina. 2012. Pengaruh Sukrosa terhadap Kandungan Total Fenol Minuman Rempah Tradisional (Minuman Secang). Jurnal Penelitian Pertanian Terapan. 12 (2) : 125-130. 